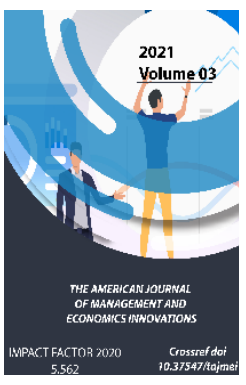

\title{
The Assessment Of Financial Management As A Tools For Control Public Sector
}

\author{
Umar Mohammed Ali \\ PhD Student Of City University Cambodia
}

Journal Website:

http://theamericanjour

nals.com/index.php/taj

mei

Copyright: Original

content from this work

may be used under the

terms of the creative

commons attributes

4.0 licence.

\section{ABSTRACT}

This study was carried out with a view of assessment of financial management as a tool for control in public sector. With special reference to ministry of finance, Borno State and to suggest on how to alleviate them. These included: (1) lack of good records keeping. (2) Mismanagement of funds and, (3) centralization of meaning financial resources in the execution of the ministry among other things: the reviewed was the review of related literature. The related was management, public sector, financial control, characteristics of financial control result in key areas, objective of financial control, and import of financial control and financial management. Following importance description of method of data collection, one hundred (100) management staff were issued to them. Some expected validity of the instrument use for the research work were personal interview. Similarly, the presentation of the various information received from the respondents were been tabulated and shown. There are various discussions in the outcome of the summary, conclusion and observed recommendations based on the outcome of the research work to the case study and of course, the acknowledgment of the various past writers used.

\section{KEYWORDS}

Management, Financial, Control, Tools, Public sector, Assessment.

\section{INTRODUCTION}

Financial management means planning, organizing, directing and controlling the financial activities such as procurement and utilization of funds of the enterprise. It means applying general management principles to financial resources of the enterprise. It is also 
the management of the finance of a business or organization in order to achieve financial objectives.

The evolution and growth of commercial and industrial undertakings has been placed alongside improvements in the techniques of management still keep pace with the everincreasing rate of technological development.

The increasing specialization within the organization of an individual business has become essential. Each division is controlled and staffed by personnel who are skilled and have the technical knowhow. We are concerned with one fact of this specialization, part of the administrative function of accounting. Modern idiom has retitled it management a ccounting but this makes one wonder whether it means accounting for management and the action they taken or accounting management; whichever both are true, but for it to operate successfully.

\section{MEANING OF FINANCIAL MANAGEMENTS}

Financial provides all discipline and all factors of human economic and social activities. It influences the psychological behavior of individuals as well as socio-cultural and economic environment of both natural and legal person (Emerson, $1904 \mathrm{p}$ 1011).

Finance has therefore evolved to assume every households, business, government and non-governmental entities cannot escape the influence of finance on their daily decisional activities.

Webster's Third International Dictionary Defined Finance as:

"The system that includes the circulation of money, the granting of credit, the making of investment and the provision of banking facilities".

This definition as to the gives indication as to the fact that finance is a system by itself, and thus a broad field of activities which the hub is of economic operation.

The shorter oxford English Dictionary defines finances "to ends and to settle debts, pay ransom, furnish, and procure e.t.c". The management of money the science of every revenue in a state cooperation provision of capitals".Another definition of finance by Christy and Roden (1973), as the study of the nature and use of the means of payment. "Management is concerned with creating and maintaining environment in which people can accomplish goals efficiently and effectively hence, control in management is the process of ensuring that action is achieved with desired goals or result while financial management comprises the forecasting planning, organizing, directing, coordinating and controlling of all activities relating to the acquisition and application of the financial resources of an undertaking in keeping with its financial objectives. Creation of this environment involves integrated used of human, financial and non-financial resources for the purpose of achieving goals. It is therefore clear from the above definitions that any action taken by the ministry of finance should be in line with its desired objective to provide public service.

The importance of sound and efficient management of public finance by the ministry of finance cannot be over emphasized without efficient financial management the policies adopted by the ministry of finance and the state in general. Variety of field may be successfully implemented. But where there is 
a proper financial management it can usually facilitate approval who are among the five owners of the business and the books of prove MDAs are also audited.

\section{TYPES OF FINANCIAL MANAGEMENT SYSTEMS}

For the purpose of this study three out of the many types of financial management system are considered relevant, there are as follows:

Budgetary Control: this form of financial management mainly concerned with the overall policies and objectives of an organization this is used to ascertain the deviation from the actual performance and budgeted activities as a result of the uncertainties of economic factors which make it necessary for prices to vary.

Budgetary control involves preparation of performance budgets for capital project and recurrent expenditure. This approach employs advanced planning and estimation; examination of immediate and future financial needs of funds make it necessary to control and report performances.

The techniques of budgeting capital projects and recurrent expenditure all together form what is known as integrated budget system. It also enable the organization to organize a framework which is systematic and scientific in providing information for monitoring the effectiveness and efficiency of the budget performance.

Management accounting control: this is concerned with the preparation, monitoring and reporting on the use of working capital (cash, raw materials, etc.) in the day-to-day operations of the organization, the operational budget represents the sum total of the forecasted working capital required. Example of an operational budget is cash budget which indicates the net position to cash arrangement due to inflow and outflow of cash on the account. Here, the control and management of cash on periodic basis is of paramount importance. Activities little cash custody of cash custody of cash receipts/invoices, bank reconciliation, etc. forms major part of control.

Therefore, cash control is possible only when operational functions move according to plan and this is reflected in the inflows and outflow of cash.

Operational Control: these techniques of management deal with day to day/task such as checking attendance, controlling the work. Operation have to be kept to standard such that there could be no loss of funds e.g. store control, usage of materials etc.

\section{ELEMENT OF FINANCIALS MANAGEMENT}

\section{Defining Objectives}

The first step in financial management is expression of relevant financial objectives which are attainable, generally these objectives are usually established by the top management with the concurrence of the middle level management and the subordinate, after the objectives have been established there is need for specification.

\section{Forming Plans}

At this second stage in the financial management is to developed plans, policies and strategies are developed and implemented by top level management in their overall strategic plan. 


\section{Meaning Result}

It may be difficult to separate the financial functions from production marketing and other function, but the functions themselves can be identified. The functions of raising funds, investing them in assets and distributing returns earned assets to shareholders are respectively known as financing decision, investment decision, and dividend decision.

\section{Comparison of Result}

With predetermined objective is the last step in the element of financial management. This is to compared these results with the objectives already established and to analysis the resources to variance so that to take corrective measures.

\section{FINANCIAL CONTROL}

Oshisami (1992), defined financial control as (management processes which assures that financial resources are obtained economically and used efficiently and effectively in the accomplishment of desired goals. he further explain that, control of financial measurement function must be exercise by $t$ executive personnel if the organization is to achieve the goals established by the planning function.

However since financial management is in assurance process it include the process of decision making, it covers the entire process of monetary action emanating from the decision, it covers the part of financial management, it is also from part of planning, budgeting, accounting report and review.

\section{CHARACTERISTIC OF FINANCIAL CONTROL}

Anyanwu (1997) and Kolade (1992). View the following as the characteristic of financial control:

i. It focuses on the financial objectives

ii. It compares two types of data: predetermined or planned and actual.

iii. It permits all aspect of financial management function

iv. It is concerned with those resources, revenue and expenditure which can be expressed in monetary term or can be considered with other quantitative data to express some personal materials, procurement etc.

v. It follows a definite cycle i.e. it is rhythmic as in the budget cycle, accounting cycle, and auditing cycle.

vi. To be effective, it needs to be coordinated and integrated.

\section{TYPES OF FINANCIAL CONTROL}

According to Oshisami (1992). Financial control can be classified in to different categories, based on what aspect is to be controlled, mode of effecting control management focus and the control system design. These categories are discussed below:

\section{a. External Control}

This is a control management system operating independently of an organization or system. It focuses on accountability and stake warding its characteristic arising from its independence of positive include fairness, credibility, reality and lack of prejudice in the federal system like ours, external audit. This refers to the examination of accounting records of all government undertaking ensure strict compliance with statutes, rule and financial regulations. It also ensure that all monies approved and allocated to each 
services are judiciously used and applied for the purpose intended for and where there are contraventions, adequate explanations should be brought to or the matter brought to light.

There is also the public account commission (PAC) which is charged with the responsibility of reviewing the book of accounts prepared by the accountant general of the federation and the auditor general in the federation report on these account. However, the citizens as integral part of the nation are not working hard enough to increase the nation earning. And it serves as formal way to communicate the plan of an establishment to the accounting officers, accounting official with delegated duties.

\section{Advantages of External Control}

i. It facilitate efficiency and proper utilization of resources.

ii. It stimulate and encourage the staff to be at their productive base.

\section{b. Internal Control}

This refers to the system of controls, financial or otherwise, established by management to assist it carry out its functions in an

\section{CONCLUSION}

The following conclusion were reacted:

(1) There is gross shortage of qualified accounting personnel especially in the finance headquarters Maiduguri. Almost all, the accounting staff are old enough to be retired. And there are no relational (transfer of staff) because there are staff with minimum qualification and lack of proper financial management and effective financial control.

(2) There is no well financial control in the ministry of finance in Maiduguri i.e. There is no segregation of duties as a single staff carries out transaction from inception to conclusion.

(3) Lack of regular auditing of financial control statement which does not allow for effective accountability and financial control in the public sector because, the financial statement of every ministry were brought to finance headquarters yearly for auditing.

(4) The researcher have examine the effect of budget indiscipline and disclosed that, it is an inherent factor affecting financial control and management in the ministry of finance Borno State

\section{REFERENCES}

1. Abu Hassan (2001) public financial management reform in less Developed countries. Publication: Lagos corporate publisher'sVentures 2001. 472p. Pbc. Date 2001.

2. Anyanwu, U. E. O. and E. A. Ukpong (1997) Revitalizing Nigeria's Economy in the public sector, second edition p. 2013 publication By Chyzon concept, Owerri, Imo State Nigeria.

3. Bamidele Adewuyi (1985) financial control and accountability in public sector, VIKAS publishing house PVT Ltd. 9780230300248.

4. Emerson (1904) management of public finance, public world heritage encyclopedia, Bauer, Scott Charless P 1011, 9613067: ISBN6-1402-1904-3.FACT and data from ministry finance Borno State (2017). UK: Blackwell publishers. 
Doi: https://doi.org/10.37547/tajmei/Volume03Issue06-05

5. Oshisami (1992) financial control in the public sector rules and regulations, Mindex publishers Benin City, Nigeria: 9780273018889.The shorter Oxford English Dictionary Webster third international dictionary. 